\section{Growth and Physiological Response of Creeping Bentgrass To Elevated Night Temperature}

\author{
Jinmin $\mathbf{F u}^{1}$ \\ Department of Horticulture, Forestry, and Recreation Resources, Kansas State \\ University, Manhattan, KS 66506-5506
}

Bingru Huang ${ }^{2}$

Department of Plant Biology and Plant Pathology, Rutgers University, New Brunswick, NJ 08901

Additional index words. Agrostis stoloniferous, carbohydrate, turf quality, heat stress, photosynthesis, respiration, root mortality

\begin{abstract}
Growth of cool-season grasses declines with increasing temperatures. The objective of this study was to determine the effects of elevated night temperature on turf quality, root mortality, and carbohydrate metabolism in creeping bentgrass (Agrostis stoloniferous L. var. palustris (Huds.) Farw (syn. A. palustris Huds.). Plants of 'Penncross' were exposed to two night temperature regimes: $24^{\circ} \mathrm{C}$ (higher night temperature); and $19{ }^{\circ} \mathrm{C}$ (lower temperature control) under the same day temperature $\left(24^{\circ} \mathrm{C}\right)$ in growth chambers for 45 days. Prolonged exposure of plants to higher night temperature reduced turf quality, canopy photosynthetic rate, whole-plant and root respiration rates during the day, translocation of newly fixed ${ }^{14} \mathrm{C}$ assimilate to roots, and total nonstructural carbohydrate content in shoots and roots (including dead and live roots). Elevated night temperature increased root mortality and whole-plant and root respiration rates at night. Our results indicated that a decline in turf quality and increase in root dieback with high night temperature was mainly associated with increased night respiration rates of whole plant and roots and reduced carbohydrate availability.
\end{abstract}

Temperature is a major factor affecting plant growth and development. Plants can be affected in different ways by either high day or high night temperatures and by either high air or high soil temperatures (Warrag and Hall, 1984a, 1984b; Xu and Huang, 2000a, 2000b). Teeri and Stowe (1976) determined the environmental factors that influence the distributional pattern of North American $\mathrm{C}_{4}$ grass species. They found that the daily minimum temperature for July had a highly positive correlation with the relative abundance of $\mathrm{C}_{4}$ grass species, suggesting the importance of night temperature in plant adaptation to temperature. Changes in night temperatures affect both vegetative and reproductive growth of various plant species (Ivory and Whiteman, 1978; Ku et al., 1978; Papadopoulos, 2000; Warrag and Hall, 1984a, 1984b). Ivory and Whiteman (1978) suggested that night temperature affects the relative growth rate and net assimilation rate independent of day temperature for several perennial grass species.

Creeping bentgrass is the most widely used cool-season grass on golf greens in the northern, cool climatic regions. Most active growth occurs between 15 and $24^{\circ} \mathrm{C}$ for shoots

Received for publication 16 Aug. 2001. Accepted for publication 14 May 2002.

${ }^{1}$ Graduate Research Assistant.

${ }^{2}$ Associate Professor. E-mail address: huang@ aesop.rutgers.edu and between 10 and $18{ }^{\circ} \mathrm{C}$ for roots in coolseason grasses (Beard, 1973; DiPaola and Beard, 1992). The southernmost U.S range of this grass is limited by high temperatures, particularly warmer nights associated with high humidity. Extensive research has been conducted concerning effects of high day and night temperature on the growth of cool-season grasses, including creeping bentgrass (Dipaola and Beard, 1992; Howard and Watschke, 1991; Huang et al., 1998; Huang and Gao, 2000; Krans and Johnson, 1974; Wehner and Watschke, 1984; White et al., knowledge, only one study has examined night temperature effects on cool-season tufgrasses and found that fresh root biomass of creeping bentgrass and annual bluegrass (Poа аппиа) decreased linearly with increasing nighttime root-zone temperatures from 22 to $34^{\circ} \mathrm{C}$ (Cummins et al., 1999). No study has yet considered the effect of elevated night temperature at a constant day temperature on shoot growth, root viability, and carbohydrate metabolism in creeping bentgrass. Understanding creeping bentgrass response to increasing night temperature may help develop effective cultural practices to improve turf performance in the warm climatic areas.

The present study was undertaken to investigate the effects of high nighttime temperature on turf quality, root mortality, photosynthesis, respiration, carbon allocation, and carbohydrate accumulation of creeping bentgrass under constant daytime air temperatures. 1988; Xu and Huang, 2000a, 2000b). To our
Sod pieces of creeping bentgrass (cv. Penncross) were collected from field plots, washed, and transplanted into a mixture of 9 sand : 1 fritted clay (v/v) (Profile Products, Deerfield, Ill.) in opaque polyvinylchloride tubes $(10 \mathrm{~cm}$ diameter $\times 40 \mathrm{~cm}$ long). Plants were grown in growth chambers at $20^{\circ} \mathrm{C}$ day $/ 15$ ${ }^{\circ} \mathrm{C}$ night, $600 \mu \mathrm{mol} \cdot \mathrm{m}^{-2} \cdot \mathrm{s}^{-1}$ photosynthetically active radiation, and a 14-h photoperiod for $60 \mathrm{~d}$ before day/night temperature treatments were imposed. Before and during temperature treatments, turf was mowed daily at a 3-4-mm height with an electric hair clipper, watered daily until soil moisture reached field capacity (when free drainage ceased from the bottom of the plant containers), and fertilized weekly with $50 \mathrm{~mL}$ full-strength Hoagland's nutrient solution $\left(\mathrm{NO}_{2}^{-1}\right.$ and $\mathrm{NH}_{4}^{+}$) form) (Hoagland and Arnon, 1950).

Plants were exposed to two night temperature regimes while day temperature was maintained at the same level $\left(24^{\circ} \mathrm{C}\right)$ : 1$)$ lower night temperature (LNT, $19^{\circ} \mathrm{C}$ ); and 2) higher night temperature (HNT, $24{ }^{\circ} \mathrm{C}$ ). Plants were exposed to these treatments for $45 \mathrm{~d}$. The experimental design was a completely randomized block design. Each night temperature treatment was replicated in three different growth chambers (three replicates). All measurements were made at 8,21 , and $44 \mathrm{~d}$ of treatment. Each measurement was made in three replicated tubes for each temperature treatment on a given day. Effects of temperature, time of treatment, and their interactions were determined by analysis of variance (ANOVA) according to the general linear model procedure of Statistical Analysis System (SAS Inst., Cary, N.C.). Differences among treatments were determined by the least significance difference (LSD) test at the 0.05 probability level.

Turf quality was visually rated based on color, density, and uniformity on a scale of 0 (worst, plants dead and brown) to 9 (best, plants healthy and green). Grasses rated at 6 or above were considered to have acceptable quality.

Root mortality was measured using the method of Knievel (1973). Samples of 1.5 to $3.9 \mathrm{~g}$ fresh roots were incubated with 20 mL $0.6 \%$ 2,3,5-triphenyltetrazolium chloride in $0.05 \mathrm{M}$ phosphate buffer $(\mathrm{pH} 7.4)$ for $24 \mathrm{~h}$ at $30{ }^{\circ} \mathrm{C}$. The roots were rinsed twice with deionized water. Formazan was extracted twice with $95 \%$ ethanol at room temperature for $24 \mathrm{~h}$. Combined extractant was brought to a final volume of $50 \mathrm{~mL}$. Absorbency was read at $490 \mathrm{~nm}$ with a spectrophotometer (Hitachi U-1100; Hitachi, Tokyo). A standard curve was made using different proportions of living roots and roots killed in an autoclave to calculate root mortality, which was expressed as the proportion of dead root dry weight in the total root dry weight.

Rates of $\mathrm{CO}_{2}$ fixation and evolution per unit turf area were measured by enclosing the turf canopy in a transparent plexiglass chamber (10 $\mathrm{cm}$ diameter $\times 5 \mathrm{~cm}$ deep). The bottom of the chamber was tightly fitted over the plant 
container. The chamber was attached to a LI-COR 6400 gas exchange system (LI-COR, Lincoln, Neb.). Respiration rate (rate of $\mathrm{CO}_{2}$ evolution) of whole plants (shoots and roots), roots, and sand and fritted clay mix without grasses growing $\left(\mathrm{R}_{\text {soil }}\right)$ was measured at daytime and nighttime. Turf net photosynthetic rates $\left(\mathrm{P}_{\mathrm{n}}\right)$ was the sum of the rate of $\mathrm{CO}_{2}$ uptake and $R_{\text {soil }}$ measured from 10:00 to $16: 00 \mathrm{~h}$ of the day. Respiration rate of whole shoots at daytime from 10:00 to $14: 00 \mathrm{~h}\left(\mathrm{R}_{\text {shoot-day }}\right)$ and nighttime from 19:00 to 20:00 ( $\left.R_{\text {shoot-night }}\right)$ was determined by subtracting $R_{\text {soil }}$ and root respiration rate at daytime $\left(\mathrm{R}_{\text {root-day }}\right)$ and at night $\left(\mathrm{R}_{\text {root-night }}\right)$ from that of whole-plant and soil (Biscoe et al., 1975; Xu and Huang, 2000b). Both $R_{\text {root-day }}$ and $R_{\text {root-night }}$ were measured immediately after shoots were removed following the measurement of whole-plant respiration rate. Four replicates (pots) of each treatment were destructively sampled at each measurement date. The growing medium (sand and fritted clay mix) was autoclaved before planting to minimize microbial activity for root respiration measurement. $\mathrm{R}_{\text {soil }}$ was measured in PVC tubes containing the same sand and fritted clay mix as for the root respiration measurement, which was subjected to the same irrigation, fertilizer, and fungicide programs as the grassed tubes.

Carbon allocation was examined using a radioactive labeling technique at the end of the experiment. Plants were labeled with ${ }^{14} \mathrm{CO}_{2}$ at $1000 \mathrm{HR}$. Shoots were enclosed in a transparent plexiglass chamber $(15 \mathrm{~cm}$ tall and $10 \mathrm{~cm}$ diameter) fitted tightly to the PVC plant container and exposed for $20 \mathrm{~min}$ to 40 $\mu \mathrm{ci}{ }^{14} \mathrm{CO}_{2}$ that was released from $\mathrm{Na}_{2}{ }_{2}^{14} \mathrm{CO}_{3}(68$ $\mu \mathrm{ci} \cdot \mathrm{mol}^{-1}$ ) by reacting with $1 \mathrm{~N} \mathrm{HCl}$. After the 20-min labeling, excessive ${ }^{14} \mathrm{CO}_{2}$ was absorbed by bubbling the gas through a saturated $\mathrm{NaOH}$ solution for $20 \mathrm{~min}$. Shoots and roots were harvested at 24, 48, and $72 \mathrm{~h}$ after labeling. Both shoots and roots were killed in an oven at $105{ }^{\circ} \mathrm{C}$ and dried at $85^{\circ} \mathrm{C}$. Tissues were then ground with a tissue grinder, and stored separately in sealed vials for analyses of ${ }^{14} \mathrm{C}$ activity and carbohydrates. The ${ }^{14} \mathrm{C}$ activity in shoots and all (dead and live) roots was measured with a liquid scintillation analyzer (Packard Tri-Carb; Beckman, Deers Grove, Ill.). The percentage of ${ }^{14} \mathrm{C}$ allocated to shoots and root was calculated.

Total nonstructural carbohydrate (TNC) concentration of shoots and all roots was measured using the method described by Chatterton et al. (1987).

\section{Results and Discussion}

The ANOVA detected significant $(P<$ $0.05)$ main effects of temperature and date of evaluation for all parameters examined. There were significant interactions between date and temperature for all parameters, except for $\mathrm{R}_{\text {shoot-night }}$ and $\mathrm{R}_{\text {root-night }}$. Therefore, the results are presented to compare temperature effects at a given day of treatment to evaluate the progression of the effect of elevated temperature for each parameter.

Turf quality of plants exposed to elevated night temperature (HNT) was lower than that of plants exposed to lower night temperature (LNT) under the same day temperature conditions at 21 and $44 \mathrm{~d}$ of treatment (Table 1). In contrast, root mortality of HNT plants was significantly higher than that of LNT-treated plants during this treatment period (Table 1). The results indicate that increasing night temperature alone can be detrimental for turf and root growth of creeping bentgrass. Papadopoulos (2000) reported that shoot growth of cucumber (Cucumis sativus L.) decreased with increasing night temperature. Blackshaw and Entz (1995) found that root biomass of Erodium cicutarium was little affected by day temperatures, but decreased substantially as night temperature increased from 12 to $24^{\circ} \mathrm{C}$.

Canopy net photosynthetic rate $(\mathrm{Pn})$ of LNT-treated plants was not significantly different from that of HNT-treated plants until $44 \mathrm{~d}$ of treatment (Table 2). The late response of Pn to night temperature suggests that photosynthesis of creeping bentgrass was not sensitive to changes in the night temperature. Gent et al. (1979) also reported insensitivity of photosynthesis to night temperature changes in tomato (Lycopersicon esculentum Mill.). However, elevated night temperature reduced daytime $\mathrm{R}_{\text {shoot-day }}$ and $\mathrm{R}_{\text {root-day }}$ by $21 \%$ and $26 \%$, respectively, during the entire experimental period (Table 2). Nighttime $R_{\text {shoot-night }}$ and $R_{\text {root-night }}$ was increased by $20 \%$ and $44 \%$, respectively, with elevated night temperature. The changes in $\mathrm{R}_{\text {root-day }}$ and $\mathrm{R}_{\text {root-night }}$ with elevated night temperature were more pronounced than $\mathrm{R}_{\text {shoot-day }}$ and $\mathrm{R}_{\text {shoot-night }}$, suggesting that root respiration was more sensitive to increasing night temperature than shoot respiration. The results indicate that turf quality decline and increase in root mortality with elevated night temperature was associated more with the increase in shoot

Table 1 . Turf quality and root mortality of creeping bentgrass in response to changes in night temperature.

\begin{tabular}{lccc}
\hline $\begin{array}{l}\text { Days of } \\
\text { treatment }\end{array}$ & $\begin{array}{c}\text { Night } \\
\text { temp } \\
\left({ }^{\circ} \mathrm{C}\right)\end{array}$ & $\begin{array}{c}\text { Turf } \\
\text { quality }\end{array}$ & $\begin{array}{c}\text { Root } \\
\text { mortality } \\
(\%)\end{array}$ \\
\hline 8 & 24 & 7.1 & 13.2 \\
& 19 & 7.4 & 11.7 \\
21 & 24 & $6.6^{*}$ & $24.2^{*}$ \\
44 & 19 & 8.0 & 14.7 \\
& 24 & $5.9^{*}$ & $33.6^{*}$ \\
\hline
\end{tabular}

"Significant difference between temperature treatments at a given day of treatment based on a least significant difference test $(P=0.05)$. and root respiration rates at night, particularly root respiration rate, rather than with canopy net photosynthesis. Although the energy and catabolic intermediates produced by respiration are essential to basic function of the plant root system, root biomass would be increased if respiration could be minimized (McCree, 1974), because roots are major carbohydrate consumers (Lambers, 1985). Therefore, turf quality and root viability in creeping bentgrass could be maintained with lowering night temperatures by reducing carbohydrate consumption of roots. Lambers (1985) reported that cooler nights should minimize the loss of carbohydrates associated with maintenance and uncoupled respiration, leaving more available for growth, storage, and pigment production.

The increased root respiration rate under elevated night temperature may accelerate the loss of respiratory carbohydrates from roots, leading to the decline in carbohydrate availability. Shoots of LNT-treated plants had significantly higher TNC content than HNTtreated plants at 21 and $44 \mathrm{~d}$ of treatment. Significantly higher TNC concentration in roots of LNT-treated plants than HNT-treated plants was detected during the entire experimental period (Table 3). Elevated night temperature increased the proportion of ${ }^{14} \mathrm{C}$ allocated to shoots following 48 and $72 \mathrm{~h}$ labeling, but reduced the proportion of ${ }^{14} \mathrm{C}$ allocated to roots (Table 4). These results suggest that the reduction in TNC accumulation and allocation of newly fixed ${ }^{14} \mathrm{C}$ assimilates to roots at elevated night temperature could be associated with the increased root mortality. The cause and effect relationship between carbohydrate content and root mortality was not determined in this study. Ku et al. (1978) found that night temperature did not affect the accumulation of nonstructural carbohydrates during the day or depletion from the leaves at night in switch grass (Panicum virgatum). Wilson and Bailey (1971) also found that orchardgrass (Dactylis glomerata) grown under higher temperature had lower starch than that grown at lower night temperature and suggest that the effect of higher night temperature is mainly on starch breakdown and mobilization in the dark rather than on synthesis.

In summary, our results demonstrated that changes in night temperature alone could have dramatic effects on turf and root growth. Enhanced turf quality and root viability by lowering night temperature could be related

Table 2. Canopy photosynthesis $(\mathrm{Pn})$, shoot daytime $\left(\mathrm{R}_{\text {shoot-day }}\right)$ and nighttime respiration $\left(\mathrm{R}_{\text {shoot-night }}\right)$, and root daytime $\left(\mathrm{R}_{\text {root-day }}\right)$ and nighttime respiration $\left(\mathrm{R}_{\text {root-night }}\right)$ of creeping bentgrass in response to changes in night temperature.

\begin{tabular}{|c|c|c|c|c|c|c|}
\hline \multirow{2}{*}{$\begin{array}{l}\text { Days of } \\
\text { treatments }\end{array}$} & \multirow{2}{*}{$\begin{array}{l}\text { Temp } \\
\left({ }^{\circ} \mathrm{C}\right)\end{array}$} & \multicolumn{3}{|c|}{ Shoot respiration rate } & \multicolumn{2}{|c|}{ Root respiration rate } \\
\hline & & Pn & $\mathrm{R}_{\text {shoot-day }}$ & $\mathrm{R}_{\text {shoot-night }}$ & $\mathrm{R}_{\text {root-day }}$ & $\mathrm{R}_{\text {root-night }}$ \\
\hline & & --1 & ---1 & $\mathrm{~mol} \cdot \mathrm{m}^{-2} \cdot \mathrm{s}$ & ) - & ---- \\
\hline \multirow[t]{2}{*}{8} & 24 & 9.93 & 6.45 & $7.73^{*}$ & 58.77 & $50.17^{*}$ \\
\hline & 19 & 9.76 & 7.55 & 5.38 & 58.09 & 12.66 \\
\hline \multirow[t]{2}{*}{21} & 24 & 14.23 & $8.43^{*}$ & $7.43^{*}$ & $46.66^{*}$ & $46.65^{*}$ \\
\hline & 19 & 13.77 & 9.74 & 5.81 & 65.78 & 25.36 \\
\hline \multirow[t]{2}{*}{44} & 24 & $13.78^{*}$ & $7.73^{*}$ & $5.90^{*}$ & $37.40^{*}$ & $43.15^{*}$ \\
\hline & 19 & 15.97 & 10.13 & 6.38 & 51.67 & 38.78 \\
\hline
\end{tabular}

"Significant difference between temperature treatments at a given day of treatment based on a least significant difference test $(P=0.05)$. 
Table 3. Total nonstructural carbohydrate content of creeping bentgrass in response to changes in nigh temperature at 8,21 , and $44 \mathrm{~d}$ of treatment.

\begin{tabular}{|c|c|c|c|}
\hline \multirow{2}{*}{$\begin{array}{l}\text { Days of } \\
\text { treatments }\end{array}$} & \multirow{2}{*}{$\begin{array}{l}\text { Temp } \\
\left({ }^{\circ} \mathrm{C}\right)\end{array}$} & \multicolumn{2}{|c|}{$\begin{array}{l}\text { TNC content } \\
\left(\mathrm{mg} \cdot \mathrm{g}^{-1} \mathrm{DW}\right)\end{array}$} \\
\hline & & Shoot & Root \\
\hline \multirow[t]{2}{*}{8} & 24 & 184 & $149^{*}$ \\
\hline & 19 & 183 & 168 \\
\hline \multirow[t]{2}{*}{21} & 24 & $166^{*}$ & $136^{*}$ \\
\hline & 19 & 180 & 151 \\
\hline \multirow[t]{2}{*}{44} & 24 & $157^{*}$ & 99* \\
\hline & 19 & 170 & 110 \\
\hline
\end{tabular}

*Significant differences between temperature treatments at a given day of treatment based on a least significant difference test $(P=0.05)$.

Table 4. Allocation of ${ }^{14} \mathrm{C}$-assimilate to shoots and roots of creeping bentgrass in response to changes in night temperature at 24,48 , and $78 \mathrm{~h}$ of labeling following $45 \mathrm{~d}$ of treatment.

\begin{tabular}{lccc}
\hline Hours & & & \\
following & Temp & \multicolumn{2}{c}{${ }^{14}$ C-assimilate $(\%)$} \\
\cline { 3 - 4 } labeling & $\left({ }^{\circ} \mathrm{C}\right)$ & Shoot & Root \\
\hline 24 & 24 & 85.97 & 14.03 \\
& 19 & 83.64 & 16.36 \\
48 & 24 & $85.58^{*}$ & $14.42^{*}$ \\
72 & 19 & 78.91 & 21.09 \\
& 24 & $74.92^{*}$ & $25.08^{*}$ \\
& 19 & 66.29 & 33.71 \\
\hline
\end{tabular}

*Significant differences between temperature treatments at a given day of treatment based on a least significant difference test $(P=0.05)$.

to increased carbon allocation to roots and reduced root respiration rates.

\section{Literature Cited}

Beard, J.B. 1973. Turfgrass: Science and culture Prentice-Hall, Englewood Cliffs, N.J.

Blackshaw, R.E. and T. Entz. 1995. Day and night temperature effects on vegetative growth of Erodium cicutarium. Weed Res. 35:471-476.
Biscoe, P.V., R.K. Scott, and J.L. Monteith. 1975. Barley and its environment. III. Carbon budget of the stand. J. Appl. Ecol. 12:269-293.

Chatterton, N.J., P.A. Harrison, J.H. Bennett, and W.R. Thornley. 1987. Fructan, starch, and sucrose concentrations in crested wheatgrass and redtop as affected by temperature. Plant Physiol. Biochem. 25:617-623.

Cummins, H.D, T.W. Rufty, andF.H., Yelverton. 1999 Root growth responses of 'Penncross' creeping bentgrass and annual bluegrass to various diurnal root-zone temperatures. Agron. Abs. 91:139.

DiPaola, J.M. and J.B. Beard. 1992. Physiological effects of temperature stress, p. 231-262. In: D.V. Waddington, R.N, Carrow, and R. Shearman (eds.). Turfgrass Monogr. No. 32. ASA, CSSA and SSSA, Madison, Wis.

Gent, M.P.N, J.H. Thorne, and D.E. Aylor. 1979. Split night temperature in a greenhouse: The effect on the physiology and growth of plants. Conn. Agr. Expt. Sta. Bul. 78:1-15.

Hoagland, C.R. and D.I. Arnon. 1950. The solutionculture method for growing plants without soil. California Agr. Expt. Circ. 347.

Howard, H. and T.L. Watschke. 1991. Variable hightemperature among Kentucky bluegrass cultivars. Agron. J. 83:689-693.

Huang, B., X. Liu, and J.D. Fry. 1998. Shoot physiological responses of two bentgrass cultivars to high temperature and poor soil aeration. Crop Sci. 38:1219-1214.

Huang, B. and H. Gao. 2000. Growth and carbohydrate metabolism of creeping bentgrass cultivars in response to increasing temperature. Crop Sci. 40:1115-1120.

Ivory, D.A. and P.C. Whiteman. 1978. Effect of temperature on growth of five subtropical grasses. I. Effect of day and night temperatures on growth and morphological development. Aust. J. Plant Physiol. 5:131-148.

Knievel, D.P. 1973. Procedures for estimating ratio of live and dead root dry matter in root core samples. Crop Sci. 13:124-126.

Krans, J.V. and G.V. Johnnson. 1974. Some effects of subirrigation on bentgrass during heat stress in the field. Agron. J. 66:526-530.

Ku, S.B., G.E. Edwards, and D. Smith. 1978. Photo- synthesis and nonstructural carbohydrate in leaf blade of Panicum virgatum as affected by night temperature. Can. J. Bot. 56:63-68.

Lambers, H. 1985. Respiration in intact plants and tissues; its regulation and dependence on environmental factors, metabolism and invaded organisms, p. 418-473. In: R. Douce and D.A. Day (eds.). Encyclopedia of plant physiology, new series. Vol. 18. Springer-Verlag, Berlin.

McCree, K.J. 1974. Equations for the rate of dark respiration of white clover and grain sorghum, as functions of dry weight, photosynthetic rate, and temperature. Crop Sci. 14:509-514.

Papadopoulos, A.P. and X.M. Hao. 2000. Effects of day and night air temperature on growth, productivity and energy use of long English cucumber. Can. J. Plant Sci. 80:143-150.

Teeri, J.A. and L.G. Stowe. 1976. Climate pattern and the distribution of $\mathrm{C}_{4}$ grasses in North America. Oecologia 23:1-12.

Warrag, M.O.A. and A.E. Hall. 1984a. Reproductive responses of cowpea [Vigna unguiculata (L.) Walp.] to heat stress: I. Responses to soil and day air temperatures. Field Crop Res. 8:3-16.

Warrag, M.O.A. and A.E. Hall. 1984b. Reproductive responses of cowpea [Vigna unguiculata (L.) Walp.] to heat stress: II. Responses to night air temperatures. Field Crop Res. 8:17-33.

Wehner, D.J. and T.L. Watschke. 1984. Heat stress effects on protein synthesis and exosmosis of cell solutes in three turfgrass species. Agron. J. 76:16-19.

White, R.H., P. Stefany, and M. Comeau. 1988. Preand post-stress temperature influence perennial ryegrass in vitro heat tolerance. HortScience 23: 1047-1051.

Wilson, D. and R.W. Bailey. 1971. Factors affecting starch in leaves in some temperate grasses. J. Sci. Food. Agr. 22:335-337.

$\mathrm{Xu}$, Q. and B. Huang. 2000a. Growth and physological responses of creeping bentgrass to changes in air and soil temperatures. Crop Sci. 40:1363-1368.

Xu, Q. and B. Huang. 2000b. Effects of differential air and soil temperature on carbohydrate metabolism in creeping bentgrass. Crop Sci. 40: 1368-1374. 